\title{
Sanctions in Silhouette: An Inquiry Into the Enforcement of the Federal Food, Drug, and Cosmetic Act ${ }^{\dagger}$
}

H. Thomas Austern*

$A$ s VoltaIRE once said of the divinity, if federal administrative agencies would have become necessary to invent some substitute for them.

When I began practicing in Washington in 1931, there appeared to be no well-defined area known as administrative law. There was, of course, Patent Office practice with its own esoteric vocabulary and rules, but it was largely confined to a group of specialists. A few lawyers had dealings with the Shipping Board; other largely confined specialists practiced before the Interstate Commerce Commission; and there were a great many tax lawyers who shared that lucrative pasture with accountants.

Some hardy attorneys wore out their lives in the interminable hearings that followed Trade Commission conplaints. But only a handful of active practitioners had anything to do with the Bureaus of Fisheries or Steamboat Inspection in the Department of Commerce, or with the Food and Drug Administration then in the Department of Agriculture, or with the then relatively new and developing Federal Radio Commission.

In 1931, the work of any lawyer before any one of these agencies was regarded as a unique specialty, isolated in substantive content and procedure, and in inost respects unrelated to any other field of law. There was no Federal Register. One seldoin sought to discern any common patterns in how each of the separate agencies operated, in whether they gave adequate notice of what they planned to do, in the type of formal findings they made, or in the mode and scope of possible judicial review of their action. There was indeed no administrative law, but only a linited group of unrelated and fragmented specialties.

Moreover, at least half of those who dealt with administrative agencies were not lawyers. They either were other specialists-chemists, engineers, or accountants-or were simply experienced and often talented men who had through previous employment in the agencies acquired what Mr. Jus-

† This article is drawn from a part of an address delivered to the Round Table Meeting on Legistation, 1962 Annual Meeting of the Association of American Law Schools, Chicago, Mlinois, Dec. 28, 1962.

* Member, District of Columbia Bar; Adjunct Professor of Law, New York University School of Law. 
tice Frankfurter termed expertise. Others were lame duck politicians whose chief competence lay in opening doors.

Most of those with a legal diploma who ventured to deal with federal agencies had never been exposed to a law school course bearing that title or with the content of those now offered. They had never had the advantage of that acrid analysis that students malke of their professors' classroom observations, or the insights that professors and students contribute to the monumental writings in administrative law.

Relatively, the legal literature on administrative law was fairly slim. There were a few discussions here and there on public utility commissions, some volumes on the Interstate Commerce Commission, Gerard Henderson's brilliant book on the early Federal Trade Commission, ${ }^{1}$ but nothing like the current Niagara of horn books, articles, and notes and comments for citation im case books and dissection by students. A few legal Tories were disquieted in 1931 about the loose procedures that the then active agencies followed, but the bulk of the Bar appeared to be content to leave administrative practice at the federal level to the Washington specialists, who presumably were familiar with its procedural quirks and with the corridors of the World War I temporary buildings in which the agencies were housed.

It was the broad exertion of administrative authority over wide segments of the American economy in the first hectic days of the New Dealparticularly by the NRA Blue Eagle, the Agricultural Adjustment Administration, the SEC, and a host of other new agencies-that first brought to most American lawyers a consciousness of the federal administrative process as a mode of government.

By 1939, when the first Attorney General's Committee on Administrative Procedure began its labors, it could point to seventeen federal administrative agencies that had come into being since 1930, and, in its report in 1941, to a total of 111 federal departments, bureaus, divisions, and independent agencies which were by then in full bloom. ${ }^{2}$

There was, and is still, room for debate as to how many federal regulatory agencies importantly affect private interests through rule making or adjudication. But what cannot be denied is that since World War II most of these agencies have vastly expanded their activities, have sharpened their formal and informal proceedings, have fared better or worse at the hands of the reviewing courts, and have successfully complied with or evaded the Administrative Procedure Act of $1946 .^{3}$

1 Henderson, The Federax Trade Conartssion (1924).

2 U.S. Dep't of Justice, Final Report of the Atrorney General's Comantitee on Adartisistrative Procedure 10 (1941).

360 Stat. 237 (1946), 5 U.S.C. \$§ 1001-11 (1958). 
As a passing paradox, the proliferation of administrative agencies has rested in large part upon their asserted efficiency and expedition in dealing with conplex regulatory probleins. Yet with each passing year the administrative process has become increasingly sluggish, criticism of inordinate delay in decision has intensified, and expedition becomes less and less a characteristic of alnuost every federal agency.

Against that background, I should like to focus on the relation between the sanctions imposed for administrative regulations and the scope and content of the authority delegated to an agency. In particular, I hope to suggest sone doubts as to the propriety of imposing criminal penalties and, perhaps, major doubts as to ever applying the concept of strict criminal liability for violation of complex administrative regulations.

As an illustrative case, I offer the Federal Food, Drug, and Cosmetic $\mathrm{Act}^{4}$ and the agency known in Washington alphabetic jargon as the FDA.

The FDA has long fascinated administrative law scholars. To begin with, the public needs to which it is directed-protection of the public health and the consumer's pocketbook-command universal approval. This was recently and dramatically demonstrated in the Drug Amendnients of $1962 .{ }^{5}$ In final form, that measure passed the Senate by a vote of seventyeight to zero, ${ }^{6}$ and the House by unanimous voice vote. ${ }^{7}$ Few enactmentsnot even a declaration of war against an aggressor-have commanded like unanimity on both sides of Capitol Hill.

Since organized government was first created, everyone has wanted the sovereigu to protect the population against impure food, deleterious drugs, and any debasement or adulteration of what a inan puts down his gullet. As Mr. Justice Frankfurter observed three years ago in the Smith case, ${ }^{8}$ in contrasting the constitutional protection of free speech with absolute criminal standards in the food and drug area: "There is an important difference in the scope of the power of a State to regulate what feeds the belly and what feeds the brain."

That universal approbation of purpose has resulted in a fascinating administrative edifice - with probably the broadest powers of rule making found in the federal government. It has its own peculiar vocabulary, structure, and procedures. The applicable standards for administrative action

452 Stat. 1040 (1938), as amended, 21 U.S.C. $\$ \$ 301-92$ (1958), as amended, 21 U.S.C. §§ 301-92 (Supp. III, 1962), as amended, 21 U.S.C.A. \$\$ 321-81 (Supp. 1962).

576 Stat. 781 (1962), 21 U.S.C.A. $\$ \$ 321-81$ (Supp. 1962).

${ }^{6} 108$ Cong. REC. 16360 (daily ed. Aug. 23, 1962).

7108 Cong. Rec. 21135 (daily ed. Oct. 4, 1962).

${ }^{8}$ Smith v. California, 361 U.S. 147, 162 (1959) (concurring opinion). The Justice indicated his awareness of the relationship between the sanction employed and what is being regulated by referring to "the balance that is struck between this vital principle [scienter] and the overriding public menace inherent in the trafficking in noxious food and drugs." Ibid. 
are as elusive as they are semantically colorful. Enforcement is achieved through the triple sanction of seizure, injunction, and criminal prosecution. Most significant for the immediate inquiry is that the most rigid concepts of strict criminal hability are apphicable.

A full description of what the FDA can regulate by its rule makingand of its unique procedures-would, and in many law schools does, warrant a full seminar. A few significant highlights must suffice here as background for our principal inquiry.

As originally conceived in 1906, and amplified in 1938, the statute was an intricate complex of prohibitions. The FDA was essentially a policing agency. Food, drug, and cosmetic manufacturers had responsibility for compliance. Seldom was court action needed. Instead, the bulk of enforcement action was informal.

A developed cooperation between the regulated industries and the enforcement agency, the drastic sanctions, the desire on the part of most to comply, the fear of adverse publicity on branded foods and proprietary drugs, and the black shadow of strict criminal liability, combined to create what I have elsewhere called a systein of "jaw-bone enforcenient."

Professor Davis has termed this type of administrative reliance on informal methods of enforcement the use of the agency's "supervising power." Administrative enforcement often does not require formal adjudication but nerely "the lifted eyebrow," the suggestion, or the implied threat of action or publicity. It is, of course, not unique to the FDA.

The informal exertion of authority in questionable areas is often employed in many other agencies. The Federal Communications Commission notably uses correspondence rather than formal proceedings-backed by the threat of the sanction of nonrenewal of a license or refusal to accord additional facilities. Indeed, its enforcement of the original "equal time" section of its act through informal procedures ultimately led to congressional aniendment.

The Securities and Exchange Commission uses the "deficiency letter," which leads alniost invariably to acquiescence by the proposed issuer-over whose head hangs the possibility of a stop-order proceeding. The Civil Aeronautics Board has firmly entrenched itself in a nuniber of areas of doubtful jurisdiction merely through correspondence and negotiation, where the shadow of a suspension order leads to the adoption of the Board's suggestions.

These informal methods of administrative enforcement are subject neither to the procedural safeguards of the Administrative Procedure Act nor to any effective judicial review. Whether one likes it or not, this mode

91 Davis, Admonvistrative Law Treatise $\$ 4.01$, at 233 (1958). 
of administrative enforcement constitutes the bulk of regulatory action. The court cases bear about the same relation to total agency conduct as the visible portion of an iceberg does to what lies beneath the surface of the sea.

By and large, however, the use of informal procedures is found in those administrative agencies having policing functions. Their employment in the enforcement of complicated agency rule making is more questionable, and turns, I suggest, entirely upon the severity of the available sanctions. Where these are economically severe--such as the loss of a television franchise-there are many who believe that periodic congressional scrutiny is warranted and salutary. But where the available sanction is the threat of a criminal prosecution for failure to obey, and where the penal proceeding is based on strict criminal liability, I believe more pointed inquiry is warranted.

The FDA is a striking example. Over the past decade, through a series of vast and intricate amendments, the FDA has had added to its policing powers under the original enactments a sweeping licensing structure. This system covers the prior approval of agricultural pesticides in very broad, detailed, and effective fashion despite whatever doubts Rachel Carson may have recently suggested. ${ }^{10}$

All new food ingredients for man and animals are now subject to prior approval. Most antibiotics must be batch-certified. As the public learned in the recent Thalidomide episode, the safety of all new drugs is subject to prior clearance. By the recent amendment, the efficacy of all new forms of drugs must likewise surmount prior detailed administrative scrutiny and approval. Beginming next year, the use of all colors for foods, drugs, and cosmetics will be brought under full licensing control.

Just a year ago, in the Federal Hazardous Substances Labelling Act, ${ }^{11}$ the FDA was also given regulatory control over every household article that is not a food or drug or cosmetic, to determine which should be dedominated "hazardous" and require cautionary labelling. This new authority covers products ranging from cleaning compounds to shoe polish.

The resulting FDA statutes are over a hundred pages long. The almost daily flow of complicated regulations, exceptions, extensions, certifications, and the like, fills and refills lrundreds of pages of fine print. Their bulk is formidable, and their technical vocabulary is as difficult to fathom as the mathematical formulae of nuclear physics.

In practical terms, the Code of Federal Regulations is as current and reliable as the old English Pipe Rolls. Indeed, in this area even the loose- 
leaf services are usually far behind the times. It takes familiarity with chemistry, pharmacology, and processing nomenclature to parse the continual supplements, deletions, revisions, and modifications. However necessary all of this may be im the public interest, it is not only delegation running riot-but it is plainly rule making not expressed in ordinary English or even familiar legal jargon.

Both basic coverage and standards for administrative action in the controlling statutes are fundamentally vague. The safety of foods and drugs and the efficacy of drugs turn on what is not "generally recognized among experts qualified by scientific training and experience." How many experts are required for general recognition-how their qualifications are to be established-and on what facts these experts are to base their judgnients -is left wholly at large.

At first glance, the necessity for the FDA establishing its basic jurisdiction by proving a negative - that the facts controlling coverage are "not generally recognized ..."-might appear to be an odd form of statutory drafting. But as we shall see, in this field what the agency concludes, the court approves; and most of those regnlated do not often dare to challenge an informal assertion of power.

The test of "fitness for consumption" is that a food may not be "filthy, decomposed, or otherwise unfit for consumption." This test is applied not in terms of what the housewife might accept, but on aesthetic criteria determinable only through a binocular microscope.

The statutory gnide for promulgating standards regnlating the composition of foods-in some respects the diet of the American consumeris phrased "to promote honesty and fair dealing in the interest of the consumers." In operation, that standard pragmatically could be equated to the more familiar guide of "effectuating the purposes of the Act."

Each of these rule-making authorities carries with it further indirect controls. For example, determining that a new food ingredient is safe for the intended use does not suffice for its authorized use. The detailed labelling of every food product in which the ingredient may be used is subject to prior administrative scrutiny lest its use, through completely safe, might in the a priori judgment of the FDA lead to collateral misbranding.

Like authority exists with respect to the use of admittedly safe food and cosmetic coloring. It extends also to so-called "New Drugs" which, though admittedly both safe and effective, now must also have their labelling and much of their advertising imitially approved by the FDA.

The statutory criteria for determining what is proper food labelling are phrased in terms of the likelihood of potential violation of the misbranding prohibitions of the rest of the act. Since these basic prohibitions are inherently vague to begin with-such as, that labeling must be "reasonably con- 
spicuous"-what is essentially authorized is a desk-top determination of an apprehension of potential illegality.

These new controls do not merely authorize prosecution for violation; they are also conditions of granting the necessary license. Interstate shipment without prior license is made criminal wholly apart from whether the food is in fact wholesome or the drug is in fact safe and effective.

What is sometimes lost sight of is that in all these agency determinations and the detailed rule making, there are not merely questions of protecting the public health; there is also a wide ambit of administrative discretion on issues of economic policy, and for the embodiment in the regulatory structure of arguable ideas about dietary preferences. These involve no hazard to health and no threat to the public, and do not remotely involve any menace "inherent in the trafficking in noxious food and drugs."

How much butter fat should be required in cottage cheese as contrasted to cream cheese - or whether pineapple chunks may be colored green-or honey added to peanut butter-or whether vitamins may be added to chocolate bars-or, to use a more familiar example, now settled by statute, whether colored margarine should be permitted to be sold-do not involve any scientific determinations or questions of public health, but instead are issues of economic policy.

Whether the per cent of polyunsaturated fats, or the ratio between saturated and polyunsaturated fats, may be disclosed to the public embodies both highly arguable nutritional theories and fundamental political questions as to how far a paternalistic or relaxed FDA should go in permitting a supposedly literate population to make its own dietary judgments.

Never forget that where the FDA disagrees, the product is outlawed. The need for or desirability of each of the elements in this FDA regulatory structure may for some be a matter of debate. It suffices for present purposes to suggest that the pattern thus far appears to be that whatever additional delegated authority may be sought in this area, Congress will usually grant it.

Our inquiry is directed toward the type of sanction that should be applied in the event of violation.

In many FDA situations, it may be wholly beyond the power of an individual to know or to control whether or not he is in compliance. A manufacturer may purchase an essential ingredient from another who may inadvertently and without negligence deliver materials which do not comply with these detailed requirements. The status of literally hundreds of ingredients remained uncertain for several years under the Food Additives Amendment of $1958 .{ }^{12}$ Many of them fell through the interstices of the 
vast network of exemptions, extensions, and exceptions embodied in the regulations.

There is, of course, in these statutes detailed provision for court review. The ordinary pattern is by petition to a United States Court of Appeals on a paper record. But every experienced food and drug lawyer will tell you that in 999 out of 1,000 cases, even the most sanguine counsel knows that he hasn't a prayer of persuading an appellate court to second-guess the FDA.

Every finding is dressed up as a scientific determination. Where there is no evidence, the FDA often resorts to negative findings-reciting that there is an absence of evidence showing that to permit the continued sale of a particular product or the use of an ingredient will benefit the consumer. Colorful phrases of remote bearing-such as "poisoming the public," "prevention of cancer," "deleterious foods injuring the public"-are regularly trotted out.

It is indeed a sturdy appellate judge who is not tempted to clutch his stomach, to recall every episode of family illness, and to react in favor of those who march under the banner of protecting the aged, lactating mothers, and infant children.

Realistically, Universal Camera ${ }^{13}$ and any other case on judicial review you care to name have little bearing in this area. The FDA rule-making process, by and large, has virtual immunity from judicial intervention or correction.

Recognition of the impracticability of judicial review probably underlies in part the recent recommendation of the Second Citizens Advisory Committee on the FDA that independent, nonagency, scientific groups should be employed as review boards. ${ }^{14}$ That idea originated and was incorporated in the Miller Amendment in 1954 for the licensing of pesticide chemicals. ${ }^{16}$ It was there provided that after the regulation was promulgated, any objecting person could have the entire regulation referred to an independent advisory committee whose recommendations were thereafter to be taken into account in re-examination by the FDA.

It may well be that some system of having an extracurricular advisory committee can be developed. As the proposals now read, I remain unpersuaded and have publicly opposed them. For the FDA to abdicate its responsibilities to a private scientific advisory committee seems to me to be objectionable. These groups will be acting privately, on evidence not of record, and, I believe, exposed to every type of direct and indirect lobbying. If the only solution to some of these problems is to create an administrative

13 Universal Camera Corp. v. NLRB, 340 U.S. 474 (1951).

14 Report of the Second Citizens Advisory Committee to the Secretary of Health, Education, and Welfare on the Food \& Drug Administration, 17 Food DRUG CosM. L.J. 581, 615-16 (1962).

1568 Stat. 511 (1954), 21 U.S.C. $\$ 346 a$ (1958). 
flying buttress to agency rule making, I think some basic re-evaluations might be preferable.

But every detailed rule and every aberrant interpretation are enforceable by penal action under strict criminal liability. Both companies and individuals are vulnerable. Indeed, as the Dotterweich case ${ }^{10}$ illustrates, the individual may be held even though the company is exonerated. Knowledge of the facts, intent, or willfulness are not required elements for conviction.

Criminal prosecution can follow with equal ease for violations of minor economic regulations as for major threatened injury to the public health. The same penal consequences can flow from using the wrong words or too small a size of type on a salad dressing label as would follow from the addition of a poison to that food. Punishment can be identical for slight exaggeration as to the contents of a bottle of suntan oil as for the failure to put a vital warning statement, or for including a false therapeutic claim, on a drug label. Accidental violation of the most intricate detailed requirement is made equally repreliensible with the willful bootlegging of toxic drugs. Employment in a food of flavoring material beyond specified levels, measured in parts per million, can be equated for criminal prosecution with the willful adulteration of drugs.

This indiscriminate application of the same drastic criminal sanction, irrespective of the character or magnitude of the violation involved, and under the absolute rule of strict criminal liability, is an listorical accident in this field. It resulted because the format of the earlier policing statutes was carried over while the delegated rule-making authority was vastly expanded. Curiously, except on civil rights issues, Congress seems to pay little attention to the form of any sanction embodied in the statutes it enacts.

You may well ask whether this drastic sanction is really employed? The unhappy answer is that it occasionally is used. Nominally, the law prescribes that there must be an administrative hearing before any criminal prosecution is ordered, and that minor violations need not be prosecuted where the FDA considers that the public interest would be adequately served by suitable written notice or warning. But, unbelievably, it has been lield that the precedent administrative hearing is not a jurisdictional requirement for prosecution. ${ }^{17}$ Moreover, in practice the FDA often uses the prerequisite Notice of Hearing more as an in terrorem technique in many situations where actual penal action miglit never be instituted.

But the real thrust of this criminal sanction of strict liability is that its very existence leads to administrative conduct which some of you might be tempted to cliallenge. Would you dare do so?

16 United States v. Dotterweich, 320 U.S. 277 (1943).

17 Ibid. 
The FDA is not unaware that it has this strict criminal sanction in back of its intricate rule-making power and its own interpretations of its own regulations. On occasion, in informal discussions of whether a regulatory proposal is authorized, or is based on any solid facts, or will have an unreasonable or discriminatory impact, one encounters the reply-offered with a smile yet with grim undertones - that these are not the real questions. The real point, it is suggested, is whether any company or company official wants "to risk being the Patsy in having the point tried out in a criminal proceeding."

Granted that this does not occur often. Granted that most of the FDA officials are the finest public servants-with no axe to grind, no set of developed predilections, and free of all elements of vindictiveness. Still, the question remains whether it is good government both to delegate this technically complicated and practically unreviewable rule-making authority, and to back it up with the sanction of strict criminal liability.

There are some who insist that the present FDA has a curious blind spot about these penal sanctions. Early in 1962 the FDA asked Congress for complete and unfettered power to inspect all of the files of every individual company subject to the act, in order to determine the existence of any violation, or potential violation, of the statute, or of any of the regulations issued under it. The only response to a suggestion that this would trespass constitutional limitations was an FDA insistence that the complexity of its own regulations and the difficulties of enforcement made this additional grant of authority necessary.

This FDA insistence, I might add, was coupled with an adamant position that full enforcement required the continuance of strict criminal liability-even absent knowledge or intent or any lack of reasonable care on the part of an inadvertent violator.

I know of no equivalent system of criminal enforcement in federal administrative law. There are some conservation statutes, such as the White Act authorizing agency determination of lawful fishing areas, where confiscation of fishing gear is authorized without inquiry into willfulness, knowledge, or intent. ${ }^{18}$ But strict criminal hability for violation of comphcated rules and regulations is, I suggest, at least a novelty.

Historically, that doctrine of strict criminal hability-which Bishop once called "too monstrous to be accepted as law"-is a development of the past 125 years. There was a parallel development in England and the United States in the statutes controlling the sale of intoxicating liquor and food. Professor Sayre suggested that the doctrine ought to be limited to

1843 Stat. 466 (1924), 48 U.S.C. $\$ 226$ (1958); see Hynes v. Grimes Packing Co., 337 U.S. 86 (1949). 
regulatory areas where the penalty was slight and the social injury resulting from violation might be widespread. ${ }^{18}$

Whatever may be the reasons for imposing a strict criminal liability for statutory rape, or selhing liquor to minors, or, as in Massachusetts, for unintentional bigamy where there was a reasonable belief that the first spouse was dead, I join with Henry Hart ${ }^{20}$ and Jeroine Hall ${ }^{21}$ in condemning the whole doctrine. In federal law, it is limited to control of narcotics, ${ }^{22}$ and food and drug law violations where, as I have suggested, imprisonment can be imposed even for offenses in no way injuring public health or safety. While I cannot warrant a search of all the substantive statutes, a runthrough of Title 18 of the United States Code has brought to light no other example except possibly section 14 of the Federal Trade Commission Act, ${ }^{23}$ which might be, but has not as yet been, interpreted to embody strict criminal liability for the false advertising of drugs where immediate and widespread danger to the public health will result. Where the substantive rules are found not in an Act of Congress but in the complex details of agency rule making, I find no other instance in which the sanction of imprisoninent follows violation according to strict criminal liability. The most that one finds is the so-called civil penalty, the amount of which is usually left to the discretion of the judge. ${ }^{24}$

In September 1962 this question as to the form of sanction to be employed for violation of administrative regulations came sharply into focus in the so-called Hart bill ${ }^{25}$ which is to be considered by the 88th Congress. The bill proposes new and comprehensive rule making to control the packaging and labeling of a broad range of "consumer commodities." It is a new

19 Sayre, Public Welfare Offenses, 33 Corom. L. Rev. 55, 78-79 (1933). Some state court decisions go further. See Ogburn v. State, 168 Ark. 396, 270 S.W. 945 (1925) (one-year imprisonment for the possession of a car having a mutilated motor number and serial number; defendant's lack of knowledge was not a defense) ; State v. Dobry, 217 Iowa 858, 250 N.W. 702 (1933) (felony conviction for filing a false statement upheld, absent any showing that defendant knew the statement to be false); State v. Lindberg, 125 Wash. 51, 215 Pac. 41 (1923) (affirming felony conviction for borrowing money from a bank of which the defendant was a director; evidence tending to show that the defendant reasonably believed that the money came from another bank was held properly excluded).

${ }^{20}$ See Hart, The Aims of the Criminal Law, 23 LAw \& ConTeMP. Prob. 401, 422-25 (1958).

21 See Hali, General Principles of Crmanal Law 325-59, 375 (2d ed. 1960).

22 Umited States v. Balint, 258 U.S. 250 (1922). But see Smith v. Cahfornia, 361 U.S. 147 (1959) ; Lambert v. California, 355 U.S. 225 (1957) ; Morissette v. United States, 342 U.S. 246 (1952) ; Baender v. Barnett, 255 U.S. 224 (1921).

2352 Stat. 114 (1938), 15 U.S.C. $\$ 54$ (1958).

24 In a forthcoming article in the Antitrust Bulletin, it is noted that the Supreme Court and the courts of appeals have now insisted that where monetary civil penalties are to apply, administrative orders must be both specific in scope and explicit in what they prohibit. In addition, the bark of these civil penalties is usually far worse than their bite.

${ }^{25}$ S. 387, 88th Cong., 1st Sess. (1963). 
form of agency economic control embracing everything from toothpaste to toilet tissue, from soup to nuts, and from paper napkins to detergents. For all products for personal or household use, it authorizes detailed regulations prescribing the sizes and shapes of packages, the unit volumes in which these products may be manufactured, the use of label illustrations, the declaration of net contents, the label type size to be employed, the use of so-called economy-size packages, "cents-off" deals, and any references to the number of servings a product may supply.

The authority to issue regulations is to be shared by the FDA and the Federal Trade Commission, depending upon whether the product is a food, drug, or cosmetic now subject to FDA enforcement, or is any other household product. The latter would be under FTC jurisdiction.

But the penalties for violation would, under present law, be wholly different-on substantially the same regulations-depending on which agency issued them. Failure to comply with a regulation issued by the FDA could mean penal enforcement with strict criminal liability. Noncompliance with the same regulation issued by the Federal Trade Commission would in contrast expose the violator only to a cease and desist order, subject to a civil penalty if not obeyed.

This proposal again illustrates the strange congressional lack of awareness or indifference to the type of sanction to be authorized for the enforcement of administrative rule making.

In discussions with FDA officials, I have found that they are extremely loath to surrender the sword of strict criminal liability. They urge that they are cognizant of the occasional unfairness of using it and that if widely employed it might not long survive. They insist, however, that it provides an understandable direct motivation for compliance with any rule or interpretation they wish to advance. Since company officials can be prosecuted even without any knowledge or intent, all subordinate employees will usually yield to FDA views rather than expose their superiors to penal prosecution. FDA also believes that no monetary consequences will be sufficiently large to act as a real deterrent.

This is all very well when the rules are simple and understandable. But when they are complicated, technical, and often neither precise in meaning nor clear in coverage, the lack of balance between the severity of the sanction, as well as its in terrorem potential, and the economic questions involved is not good government.

In my view, both revision and refinement of these sanctions would be desirable. For noncomphiance that directly endangers the public health, a criminal sanction can be accepted. Strict criminal liability cannot be countenanced.

For violation of regulations that are essentially economic, the use of a 
cease and desist order, backed up by both injunction and civil penalties for further violation, would be adequate. This is not remotely the "trafficking in noxious food and drugs" which Mr. Justice Frankfurter took as his springboard in the Smith case. ${ }^{26}$ Moreover, $\$ 5,000$ per day would seem to be a sufficient economic deterrent.

In his Holmes Lectures this year, Judge Friendly pleaded for more intensive study in the law schools of the substance of administrative law. He was talking about adjudication, not rule making. I hope that some of you in the academic cloisters who have time for study in depth, penetrating thought, and the aid of talented research assistants, may be moved to make a full and objective re-examination of this question of how the sanction for violation ought to be related to the form and subject matter of administrative regulations. 